\title{
Chapter 2 SDG 2: Zero Hunger - Challenging the Hegemony of Monoculture Agriculture for Forests and People
}

Terry C. H. Sunderland*, Alida O'Connor, Giulia Muir, Lauren Nerfa, Giulia Rota Nodari, Camilla Wildmark, Nur Bahar and Amy Ickowitz

\section{Key Points}

- A 'business-as-usual' approach to food production will continue to cause mass deforestation. This is detrimental for biodiversity, consequently impacting forest-dwelling communities who depend on forests for the direct provision of food. With the loss of forests comes the loss of farreaching ecosystem services, vital for many facets of food production relied on by the wider population.

- SDG 2 and five of its targets (Targets 2.1-2.5) are closely related to forests. These five targets underscore the reciprocity between forests and SDG 2. Forest biodiversity is integral for nutrition and the ability to grow and harvest diverse crops. In turn, investing in small-scale farming systems and sustainable farming techniques can help conserve forests.

- If we are to achieve SDG 2 sustainably, we need a reimagined food system that does not polarise agricultural production and the conservation of forest resources. This calls for land management that promotes the maintenance of biodiversity and integrated land-use planning. This is especially evident when examining the relationship between SDG 2 and the other SDGs, most of which are concomitantly contingent on each other.

\subsection{Introduction and Context}

For the majority of human history, we sustained ourselves by foraging edible plants and hunting animals encountered in grasslands, forests and other wild habitats. Indeed, much of our evolutionary development is based on a complex system of hunting and gathering, which provided a varied and nutritious diet (Gordon et al. 2017). All that changed around 10000 years ago when agriculture simultaneously emerged in various parts of the world, creating a food system that is very much dominant today (Harari 2014).

\footnotetext{
* Lead author.
} 
Agriculture dominates the global landscape. More than 40 per cent of the global land area is under some sort of cultivation, and we produce more food than ever before in human history (Ellis et al. 2010, Springmann et al. 2018). Much of this expansion has come at the expense of our forests. Agricultural expansion is also pushing other environmental boundaries. Over half of the world's freshwater is appropriated to nourish our crops, soil erosion now exceeds soil formation, chemical herbicides and pesticides result in extensive and pervasive pollution, and agriculture now accounts for around one-third of greenhouse gas emissions (Springmann et al. 2018). While this expansion has had great environmental costs, it has not necessarily resulted in better dietary and nutritional outcomes (Bahadur et al. 2018).

Our global food system is characterised by a heavy reliance on a narrow range of crops and livestock (Khoury et al. 2014). Diets across the globe have shifted from being largely plant-based with complex carbohydrates and low in fats to diets high in fats and oils, meats and refined carbohydrates (HLPE Report 2017a). As a result, almost 2 billion of our global population are over-nourished, and around the same number remain under-nourished (HLPE Report 2017a). With the latter issue, the proportion of the world's population that goes to bed hungry has actually increased in recent years (FAO et al. 2017), while almost one-third of all food produced is wasted, either post-harvest or post-purchase (FAO 2011). There are repeated calls for food production to increase by between 50 per cent and 100 per cent in order to feed an ever-growing human population - a call now echoed throughout the academic and development literature (Tomlinson 2013). In short, our global food system has failed to achieve universal food security (Vandermeer et al. 2018).

With food security and nutrition currently prominent in terms of global development priorities, we need to fully comprehend the deficiencies in our food system and the impact it has on the wider environment, including forests and other ecosystems (HLPE Report 2017b). The current global food system leaves millions of people food insecure while contributing to over-production and generating significant environmental degradation (HLPE Report 2017a). Often, however, food security is measured solely in terms of food energy (i.e. calorie production), losing sight of the fact that, by definition, food security includes secure access to the foods needed for a nutritionally balanced diet (Bahadur et al. 2018, HLPE Report 2017a, Ickowitz et al. 2019). This focus on energy production has contributed to a dichotomisation in which food production, sustainable forest management and conservation are portrayed as mutually exclusive (Brussard et al. 2010). The clear separation of biodiversity conservation and agricultural production has been an impediment in achieving optimised outcomes for either (Gordon et al. 2017). A serious reform of the current food system is clearly needed. 
The question central to this chapter is: Can we feed and nourish the growing human population without further damaging our wider environment, especially forests, in the process? Throughout the chapter we explore this question by examining SDG 2 (Zero Hunger) in relation to forests. First, we focus on the SDG 2 targets that are impacted by or will directly impact forests. This is followed by a discussion on the relationship between SDG 2 and the other SDGs in regard to forests.

\subsection{Zero Hunger and Forests}

SDG 2 seeks to 'End hunger, achieve food security and nutrition and promote sustainable agriculture' (United Nations 2015). The goal aims to end hunger and all forms of malnutrition by 2030. It also commits to 'universal access to safe, nutritious and sufficient food at all times of the year' (Table 2.1). The narrative further describes how achieving SDG 2 will require sustainable food production systems and resilient agricultural practices, equitable access to land for farmers and communities, technology and markets, and international cooperation on investments in infrastructure and technology to boost agricultural productivity. Targets 2.1-2.5 (Table 2.1) are closely entwined with forests and forest-related livelihoods. Unless agriculture and forestry are designed to coexist, the possible impacts of achieving SDG 2 on forests include increasing resource use to raise production, thereby creating more pollution (e.g. phosphorus, nitrates, fossil fuels) and higher rates of deforestation (Springmann et al. 2018).

Reflecting on this chapter's guiding question - Can we feed and nourish the growing human population without further damaging our wider environment, especially forests, in the process? - we begin to see how Targets 2.1-2.5 address this. Targets 2.1 and 2.2 can be viewed as the desired outcomes of SDG 2: to end all hunger and ensure that everyone, especially vulnerable populations, has access to nutritious food. Target 2.4 draws our attention to the need to achieve Targets 2.1 and 2.2 in a way that will sustain rather than degrade forest ecosystems. Finally, if managed correctly, Targets 2.3 and 2.5 are key to achieving SDG 2 while maintaining the ecological integrity of forests.

\subsubsection{Forests and Targets 2.1 and 2.2}

Agriculture expansion is the largest cause of deforestation, responsible for approximately 80 per cent of forest loss worldwide (HLPE Report 2017b, Kissinger et al. 2012). Recent research has found that more than one-quarter of permanent forest transformation is driven by commodity expansion, notably that of cattle, soy and oil palm (Curtis et al. 2018). This has devastating 
Table 2.1 SDG 2 targets and indicators

\begin{tabular}{|c|c|}
\hline Target & Indicator(s) \\
\hline $\begin{array}{l}\text { 2.1 End hunger and ensure access } \\
\text { by all people to safe, nutritious } \\
\text { and sufficient food, especially } \\
\text { vulnerable populations }\end{array}$ & $\begin{array}{l}\text { 2.1.1 Prevalence of undernourishment } \\
\text { 2.1.2 Prevalence of moderate or severe } \\
\text { food insecurity }\end{array}$ \\
\hline 2.2 End all forms of malnutrition & $\begin{array}{l}\text { 2.2.1 Prevalence of stunting among } \\
\text { children under } 5 \text { years of age } \\
\text { 2.2.2 Prevalence of malnutrition among } \\
\text { children under } 5 \text { years of age }\end{array}$ \\
\hline $\begin{array}{l}\text { 2.3 Double the agricultural } \\
\text { productivity and incomes of small- } \\
\text { scale food producers }\end{array}$ & $\begin{array}{l}\text { 2.3.1 Volume of production per labour } \\
\text { unit } \\
\text { 2.3.2 Average income of small-scale } \\
\text { food producers }\end{array}$ \\
\hline $\begin{array}{l}\text { 2.4 Ensure sustainable food production } \\
\text { systems and implement resilient } \\
\text { agricultural practices }\end{array}$ & $\begin{array}{l}\text { 2.4.1 Proportion of agricultural area } \\
\text { under productive and sustainable } \\
\text { agriculture }\end{array}$ \\
\hline $\begin{array}{l}\text { 2.5 Maintain the genetic diversity } \\
\text { of seeds, cultivated plants and } \\
\text { farmed and domesticated animals } \\
\text { and their related wild species }\end{array}$ & $\begin{array}{l}\text { 2.5.1 Number of plant and animal } \\
\text { genetic resources for food and } \\
\text { agriculture secured } \\
\text { 2.5.2 Proportion of local breeds classified } \\
\text { as being at risk, not at risk or at } \\
\text { unknown level of risk of extinction }\end{array}$ \\
\hline $\begin{array}{l}\text { 2.A Increase investment in rural } \\
\text { infrastructure, agricultural research } \\
\text { and extension services, technology } \\
\text { development and plant and } \\
\text { livestock gene banks }\end{array}$ & $\begin{array}{l}\text { 2.A. } 1 \text { The agriculture orientation index } \\
\text { for government expenditures } \\
\text { 2.A.2 Total official flows to the } \\
\text { agriculture sector }\end{array}$ \\
\hline $\begin{array}{l}\text { 2.B Correct and prevent trade } \\
\text { restrictions and distortions in world } \\
\text { agricultural markets }\end{array}$ & 2.B.1 Agricultural export subsidies \\
\hline $\begin{array}{l}\text { 2.C Adopt measures to ensure the } \\
\text { proper functioning of food } \\
\text { commodity markets and their } \\
\text { derivatives and facilitate timely } \\
\text { access to market information }\end{array}$ & 2.C.1 Indicator of food price anomalies \\
\hline
\end{tabular}


consequences for both forests and people. Forests contain 80 per cent of terrestrial biomass and provide habitat for more than half of the world's known terrestrial plant and animal species (Aerts and Honnay 2011, Shvidenko et al. 2005). Forests contribute directly and indirectly to food security and nutrition in numerous ways and for various groups of people (Broegaard et al. 2017, Powell et al. 2015). All those who rely to some extent on forests and trees for their livelihood can be considered forest-dependent (HLPE Report 2017b). Byron and Arnold (1997) further this definition by making a crucial distinction between those who rely on forest use and have no alternative and those who use forest products or engage in economic activities involving forests, but do so as a matter of choice.

Communities located in remote areas in and around forests are heavily dependent on forest resources for their livelihoods, especially food (Powell et al. 2015). The types of food from forests and the ways it is harvested have cultural and traditional significance to Indigenous groups (Kuhnlein et al. 2009). These groups often live as hunter-gatherers or shifting cultivators on a subsistence basis (Padoch and Sunderland 2014). Shifting cultivation, also known as swidden agriculture, involves the intermittent clearing and burning of small patches of forest for subsistence food crop production, followed by longer periods of fallow in which the forest regenerates and restores the productivity of the land (Cramb et al. 2009). Swidden agriculture is practised in many countries in the tropical regions of Africa, Asia and Latin America (Mertz et al. 2009). In places with an abundance of land and low human population, shifting cultivation can be managed sustainably to preserve biodiversity and soil fertility while contributing to food security, and can have a long-term, often beneficial, influence on the floristics and ecology of the forests concerned (Maezumi et al. 2018). However, this is less likely to be as sustainable in places with denser populations (Peng et al. 2014, Vira et al. 2015).

People who live in proximity to forests are also somewhat dependent on forests for food security and nutrition. These people are usually involved in agricultural practices either within or outside of the forest, and use forest products partly for their own subsistence and partly for income generation (HLPE Report 2017b). For those more involved in agriculture, dietary supplements from forests are of critical importance to diet diversification for a more nutritious diet (Broegaard et al. 2017). Take bushmeat for example. Bushmeat is derived from wild terrestrial animals and is a significant source of protein extracted from the forest (Nasi et al. 2011). In tropical areas where livestock production is limited and domesticated meats are unaffordable, bushmeat is an important source of micronutrients and protein (Fa et al. 2015). Relatedly, forests act as an economic and environmental safety net, helping households and communities recover from shocks (Wunder et 
al. 2014). After a poor harvest or drought, food from forests often provides dietary substitutes during periods of scarcity. In times of food insecurity, maternal food deprivation can cause childhood malnutrition and ill health, effects that can linger long into adulthood, ultimately affecting life-long productivity and health (Agarwal 2018). The role of safety net that forests play is important for the most vulnerable groups and relates directly to Targets 2.1 and 2.2 .

In addition to the direct provision of food, forest plants are used as feed for livestock, another source of meat and income generation (Baudron et al. 2017). Furthermore, forests contribute to food security and nutrition through the provision of energy. In places where people have no alternative energy sources, wood gathered from the forest is used as the main fuel for cooking. One-third of the global population relies on woodfuel for cooking (HLPE Report 2017b). The ability to cook food expands food options and is important for food safety and water purification (Jin et al. 2017).

The contributions of forests to Targets 2.2 and 2.3 reach far beyond communities living in and near forests. When discussing forest-dependent people, it is difficult to truly understand what this encompasses. Attempts to quantify the number of forest-dependent people worldwide have been made primarily using information on food and income generated from forests. However, these methods do not consider that most agricultural activities depend on ecosystem services provided by forests, which would drastically increase the number of forest-dependent people (HLPE Report 2017b). Forests deliver ecosystem services such as water regulation, soil protection, nutrient circulation, pest control, pollination and carbon-cycle regulation, all of which support food production at the farm, landscape and global scales and mitigate the impacts of climate change (Cumming et al. 2014).

Nevertheless, forests possess inherent trade-offs. They can harbour species that contribute to human wildlife conflict via crop or livestock damage, and pests or diseases that can transfer to crops, livestock and people. For example, in the United Kingdom badgers have been known to spread bovine tuberculosis to dairy cattle (HLPE Report 2017b). However, evidence shows that the benefits of forests to agriculture far outweigh the costs (Reed et al. 2017a). Moreover, the trade-offs mentioned here would still be a challenge, perhaps intensified by fragmentation and deforestation from agriculture. Loss of habitat leaves wildlife populations in search of food and water, resulting in livestock predation and competition for water and grazing land (HLPE Report 2017b).

To summarise, forests are vital to nutritious food production through the direct provision of diverse and nutritious food, energy for cooking and ecosystem services (Powell et al. 2015, Reed et al. 2017a). These contributions 
are particularly important for the nutrition and food security of vulnerable populations (Targets 2.1 and 2.2); they also impact the food security of the global population (HLPE Report 2017b). As such, the importance of conserving the ecological integrity of forests is undeniable (FAO 2019). However, the current dominant food system results from precisely the contrary: namely, a denial of this importance. This emphasises the need to bear in mind forest conservation to achieve Target 2.4's aim to 'ensure sustainable food production systems and implement resilient agricultural practices' (see Table 2.1).

\subsubsection{Forests and Targets 2.3, 2.4 and 2.5}

This section explores how the current food system polarises food production and forest conservation, when in fact they should and can be harmonised. We pay special attention to the role of maintaining genetic diversity (Target 2.5) and investing in small-scale food producers (Target 2.3) in sustainable food systems (Target 2.4) to reduce hunger and malnutrition (Targets 2.1 and 2.2), ultimately needed to achieve SDG 2 . Throughout this discussion we draw attention to the impacts of achieving these targets on forests and people.

\section{A POLARISING FOOD SYSTEM}

Agricultural expansion, production and trade, particularly in the past 100 years, have been the greatest drivers of land conversion and habitat loss, as well as the major direct cause of deforestation (Gibbs et al. 2010). More efficient and productive agriculture has now reached increasingly into marginal lands and is a major land use worldwide (Springmann et al. 2018). With this has come trade and transport, meaning agriculture is now connected to markets and finance across the globe (Swain et al. 2018). The globalisation of agribusiness has resulted in a shift from traditional wholesale markets towards vertically coordinated supply chains that favour large-scale monocrop production (FAO 2015).

Whether rapid agricultural expansion causes deforestation or takes place on previously cleared land has been missing from the conversation on agriculture for some time. A study by Gibbs et al. (2010) reveals that the total net increase in agricultural area was more than 100 million ha across tropical regions during the 1980s and 1990s. More than 55 per cent of this new land came from intact forests and 28 per cent came from disturbed forests (forests previously affected by shifting cultivation, woodfuel collection and other forms of gradual degradation). This confirms that during those decades forests were the primary source for new agricultural land, and expansion has not come from previously cleared or degraded land (Gibbs et al. 2010). This trend persists: forest-rich tropical countries with lower production costs and fewer environmental regulations are being used to meet the continuously 
growing demand for agricultural land. Much of this land is used as pasture for livestock and to grow livestock feed and commodity crops such as sugarcane, soybeans and oil palm (Curtis et al. 2018).

Nutrition transitions are occurring in tandem with deforestation and environmental change. Rural communities whose land is converted to monoculture agricultural production, such as oil palm, lose not only their forests but in many cases their formerly diverse diets sourced from multi-functional landscapes (Ickowitz et al. 2016). This can equate to cultural losses, such as the loss of foods with symbolic meanings or food required for certain traditions (Cockx et al. 2018). Clearing land with no regard for conserving biodiversity has not only diminished the dietary variety of people living in or near forests, but also that of the wider population too.

Historically, the achievement of food security has focused primarily on calorie intake rather than nutrition (Ickowitz et al. 2019). There exists today a triple burden: malnutrition, consisting of deficiencies in dietary energy intake (hunger), estimated to affect more than 800 million people worldwide in 2017; nutrient deficiencies - such as a lack of iron, iodine or vitamin A which affect some 2 billion people (2017); and the rapidly growing number of people who are overweight, estimated by the World Health Organization at 1.9 billion adults in 2016 (39 per cent of the world's adult population), of which 650 million (13 per cent) were classified as obese (HLPE Report 2017a). This is expected to intensify. As countries urbanise and incomes rise, diets tend to become high in sugar, fats, refined carbohydrates, meat and dairy (WRI 2018). Although small portions of meat and dairy can provide important micronutrients, half of the global population consume 50 per cent more protein than needed (WRI 2018). Ruminant meat (cattle, sheep, goats) consumption is expected to grow 88 per cent by 2050. Ruminant livestock uses two-thirds of global agricultural land (WRI 2018), and approximately twothirds of all soybeans, maize and barley and one-third of all grains are used as feed for livestock (Willett et al. 2019).

The EAT-Lancet Commission describes a universal healthy reference diet that links healthy foods with improved human health and environmental sustainability. The diet consists of vegetables, fruits, whole grains, legumes, nuts, unsaturated oils and low amounts of seafood and poultry. The diet recommends low to no consumption of unhealthy foods such as red meat, processed meats, added sugar, starchy vegetables and refined grains (Willett et al. 2019). Transitioning to a diet similar to the healthy reference diet requires a reduction in global consumption of unhealthy foods by more than 50 per cent (Willett et al. 2019).

Adding to the mounting concerns of the current food system is food waste. It is estimated that a third of all food grown is wasted, either post-harvest or 
post-purchase (FAO 2011). Food loss occurs along the entire food chain and has negative economic, social and environmental consequences (AschemannWitzel et al. 2015, FAO 2011). Food waste at the beginning of the food chain is prevalent in low-income countries. These losses are largely due to technical limitations in harvesting and a lack of storage and cooling facilities, as well as packaging and marketing systems (FAO 2011). Food waste in medium- and high-income countries shows an opposite trend, with most food wasted at the consumer level. This can be attributed to poor purchase planning and best-before dates, quality standards and aesthetic expectations, enabled by consumers who can afford to waste food (Aschemann-Witzel et al. 2015, FAO 2011). When food is wasted, the resources used in its production and transportation are also squandered (Aschemann-Witzel et al. 2015).

From this discussion, it is clear the production and consumption trends driven by the current food system are problematic for both people and forests. The focus on maximising the production of select commodity crops has resulted in mass deforestation for monocrop agriculture. The logic behind our current approach to agriculture has become disconnected from what agriculture is so dependent on: nature (Gordon et al. 2017) and its biodiversity (Sunderland 2011). This is made worse by the fact that the system has failed to achieve global food security and nutrition. Rather, the current system relies on a narrow range of crops, and diets have shifted to become less diverse and nutritious, negatively impacting the health of people and forests.

The complex polarisation of the approaches needed to feed current and future populations while conserving forests and the wider environment is a fundamental development issue. It has led to the protectionist paradigm of separating nature from agriculture rather than the two operating in synergy (Harari 2014). The achievement of SDG 2 is contingent on recoupling nature and agriculture. Diverse and nutritious diets are synonymous with biodiversity. Moving forward, current production and consumption trends need to change. As much as this is for the benefit of people, it presents a challenge to our current habits. Achieving SDG 2 necessitates a behavioural change in what food we consume, as well as how we manage and produce food. The following sections explore how maintaining genetic diversity (Target 2.5) and investing in smallholder farmers (Target 2.3) will help address these needed changes for a food system that is resilient (Target 2.4) and nutritious (Targets 2.1 and 2.2).

\section{TARGET 2.5: GENETIC DIVERSITY IN CROPS}

Achieving SDG 2 can improve nutrition and positively impact the health of people and forests. This requires changing a defining characteristic of our current food system: the increased reliance on only a very few species, leading to 
the increased homogenisation of diets (Khoury et al. 2014). Since agriculture began some 12000 years ago, approximately 7000 plant species and several thousand animal species have been used for human nutrition (Burlingame et al. 2012). Today, although certain traditional and Indigenous communities continue to use a multitude of species in their diets, the general global trend has been towards diet simplification, with consequent negative impacts on human food security, nutrition and health (FAO 2019, Powell et al. 2015). It is estimated that three-quarters of the varietal genetic diversity of agricultural crops has been lost over the last century (Khoury et al. 2016). Just 12 crops and 14 animal species now provide most of the world's food (Burlingame et al. 2012, Khoury et al. 2014).

As the biodiversity used in food and agriculture declines, the food supply becomes less sustainable and more vulnerable (FAO 2019). The narrowing of the genetic basis of our food systems means there is less resilience to the consequences of climate change such as droughts, floods, fires and incidences of pest outbreaks (Deutsch et al. 2018, Schipanski et al. 2016). Less genetic diversity means fewer opportunities for the growth and innovation needed to provide food security and boost agricultural production at a time of soaring food prices and competition with production for biofuels. For example, Tigchelaar et al. (2018) estimate that the predicted $4^{\circ} \mathrm{C}$ temperature increase worldwide will lead to losses of up to 87 per cent in global maize production. In addition, the nutritional value of some crops could change (Smith and Myers 2018). With increased carbon dioxide in the atmosphere it is postulated that while plant growth may indeed increase, the nutritional quality of staple crops such as potatoes, barley, wheat and rice may fall due to an increase in carbohydrate production and a reduction in protein levels (Ebi and Ziska 2018). This would have a major nutritional impact on the billions of people who rely on these staples.

Not only does relying on a few, select crops leave the food system vulnerable to climatic changes, it lacks the diversity proven to have a plethora of nutritional benefits (HLPE Report 2017a). Biological diversity includes countless plants that feed and heal people, many crop varieties and aquatic species with specific nutritional characteristics, livestock species adapted to harsh environments, insects that pollinate fields and micro-organisms that regenerate agricultural soils. As discussed in Section 2.1, forests contain most of the world's terrestrial biodiversity and provide ecosystem services vital for the survival of other ecosystems (Springmann et al. 2018). An investment in conserving forest biodiversity is an investment in future food security that is diverse, nutritious and resilient (FAO 2019).

To summarise, achieving SDG 2, specifically genetic diversity (Target 2.5), requires the conservation of biodiversity. As forests are home to most of the 
world's terrestrial biodiversity, this means forest conservation should be at the forefront of our considerations. Further, genetic diversity in our food supply benefits people in several ways. First, genetic diversity enhances dietary nutrition and health. Second, it is integral for climate change adaptation and mitigation. This helps build resilience (Target 2.4) and lessen vulnerability to shocks, thereby benefitting the socio-economic well-being of producers and those who are supported by them. Finally, genetic diversity and maintaining biodiversity, especially that of forests, helps sustain the numerous ecosystem services on which people rely. Clearing forests to grow a minimal assortment of crops is no longer an option. Forests can and should be integrated into agriculture rather than being viewed as being 'in the way' of production. The next section discusses the importance of investing in smallholder farms and enhancing biodiversity in agriculture.

\section{TARGET 2.3: INVESTING IN SMALLHOLDER FOOD PRODUCERS}

The pervasive image of modern agriculture is of a vast swath of swaying cereals tended by industrial-scale machinery. This is certainly the case in much of the temperate world. However, in the tropics most of the food produced originates in complex multi-functional landscapes, characterised by small farms producing a wide variety of products (Ricciardi et al. 2018). This diversification is critical for livelihood strategies (don't put all your eggs in one basket) as it provides resilience against both economic and environmental shocks - the latter increasingly driven by climate-induced droughts, floods and other events. Smallholder systems are estimated to produce between 30 per cent (Ricciardi et al. 2018) and 70-80 per cent (FAO 2014) of the world's food. Even with this wide range, it still represents a significant proportion of global food production.

Unlike in temperate regions, the majority of smallholder farmers in tropical regions do not benefit from national or regional subsidies (Chirwa and Dorward 2013). Post-harvest losses are considerable in these systems, yet little to no government support is available for most farmers. They stand to lose their markets due to cheap, subsidised products being dumped on their own production range (FAO 2015, McMichael 2005). In short, smallholder farmers are a resilient and productive group that contributes to global food security in often unseen ways; they deserve more support and the opportunity to compete in fair and equitable market systems. Development support should complement existing knowledge and practices within local systems.

Unfortunately, a growing worldwide trend in the demography of farmers works against such long-term support. Many farmers support their children's education, who, in turn, tend to shun farming as an occupation. As a result, farmers are growing older and less able to manage the land. There is a general 
trend for small farms to consolidate into larger production units both in temperate and tropical production systems, which is problematic because largescale commercial agriculture is the driver of approximately 40 per cent of deforestation in tropical and subtropical regions (FAO 2016).

Target 2.3 seeks to change this by doubling the agricultural productivity and income of small-scale food producers, particularly women, Indigenous peoples, family farmers, pastoralists and fishers. Smallholders would benefit from mechanisms that provide access to essential services, such as credit, electricity and transport needed to participate in agribusiness. This could be made more accessible through instruments such as group savings and loan associations, chattel mortgages and leasing (FAO 2017). Furthermore, farmers, especially youth, would benefit from opportunities to develop technical skills and entrepreneurial training. Helping smallholders build the technical capacity and access to the resources necessary to remain competitive in the food system would improve the socio-economic well-being of many.

Investing in smallholder producers is very much related to forests, as many smallholder farmers operate near forests. As discussed in Section 2.1, farmers in rural areas rely on the forest as a safety net for a bad harvest. Additionally, it is good to be near forests for the resources they provide, such as plants used to feed livestock, wood for fences and other structures, improved soil nutrients and much more. Giving smallholder farmers everywhere access to support is important for the aforementioned reasons; however, smallholder farmers near forests present a unique opportunity to conserve forest ecosystems through integrated land uses such as agroforestry (Godfray et al. 2010).

Agroforestry, as defined by Lundgren and Raintree (1982), is 'the name for land-use systems and technologies where woody perennials (trees, shrubs, palms, bamboos, etc.) are deliberately used on the same land-management units as agricultural crops and/or animals, in some form of spatial arrangement or temporal sequence. In agroforestry systems there are both ecological and economical interactions between the different components' (HLPE Report 2017b: 34). There are three classes of agroforestry systems: agrisilvicultural systems, combining agricultural crops and trees or shrubs; silvopastoral systems, combining trees and pasture for grazing livestock; and agrosilvopastoral systems, combining crops, pastures and trees (Nair 1993, Vira et al. 2015).

Trees on farms can generate an array of benefits for communities and the environment. Trees provide shade for shade-tolerant crops, which increases yields. Cocoa grown under tree shade can produce yields for 60-100 years, compared to 20 years or less without shade (Obiri et al. 2007, 2011; Ruf and Schroth 2004). Another example is the presence of fruit trees in agroforestry systems. They have been shown to help fill seasonal gaps in fruit supply (Jamnadass et al. 2011, Vinceti et al. 2013) and attract wild animals 
for hunting (Sylvester and Segura 2016). Essentially, agroforestry helps maintain biodiversity, genetic diversity and the associated benefits of forests - i.e. improved soil fertility resulting in increased crop yields, fodder for livestock, woodfuel for cooking, ecosystem services necessary for food production, etc. In some cases, agroforestry can be an appealing alternative to conservation agriculture. Conservation agriculture relies on reduced tillage of soils and preserving crop residues to prevent soil erosion. However, some farmers rely on crop residues to feed livestock (WRI 2018). Agroforestry allows this practice to continue and improves soil quality.

It is important to note that land rights are key to investing in land and pursuing long-term investment activities, such as planting trees. In much of the world, rural and forest dwellers lack registered or formalised rights to land. Recent work has drawn attention to the importance of recognising customary rights and shared rights to land and forests, as well as a need to reduce the bureaucracy and legal obstacles of granting community rights (WRI 2018).

Certification schemes and market-based mechanisms are one way of supporting agriculture that integrates forest conservation. These schemes encourage integrative alternatives to the polarising approach that has dominated thus far. Market-based mechanisms and certifications engage multiple stakeholders, including farmers, government, communities and private companies, incentivising sustainable management and production. There are numerous examples, including the REDD+ programme, that offer resultsbased payments for actions reducing forest carbon emissions, such as sustainable agriculture practices (REDD 2016).

Certifications allow an independent assessment of a defined set of management standards that promote and measure sustainable forest management (CEPI 2006, HLPE Report 2017b). Some certification schemes (e.g. The Forest Stewardship Council (FSC), and the Programme for the Endorsement of Forest Certification (PEFC)) are focused on sustainable forest management in general, while others are focused specifically on food production and forests (e.g. the Round Table on Sustainable Palm Oil (RSPO), and the Round Table on Sustainable Soy (RTRS)) (HLPE Report 2017b). These schemes are proving to be successful. Take RSPO, for example: nearly 2.5 million ha of palm oil is RSPO certified, which represents 21 per cent of global production (HLPE Report 2017b). However, forest certification is primarily focused on boreal and temperate forests, while only 6 per cent of the total certified area is in the tropics (MacDicken et al. 2015), leaving ample room for improvement.

In addition, high-income countries tend to protect their own natural resources and import from lower-income countries to sustain consumption (Mills Busa 2013). With this in mind, consumption strategies such as certification schemes can be as important a buffer to forests as protected areas (HLPE 
Report 2017b). In the same vein, it is worth noting that although protected areas are undeniably important, they can be managed in a way that is restrictive to local people and the resources needed for their diets, again reinforcing the importance of systems that sustainably integrate multiple uses.

\subsubsection{Integrated Landscape Management}

Taking what we have learned from Targets 2.1 to 2.5, a common theme emerges: the need for management that recognises the multiple uses of landscapes and the ways they impact each other (Kremen and Merenlender 2018). As this chapter has shown through the discussion of forests and agriculture, landscapes are a mosaic of natural and human-modified ecosystems that cannot be neatly separated from one another (Reed et al. 2017b). Our failing food system and degraded forests are a testament to the need for a new approach to food production (Ickowitz et al. 2019). The landscape approach answers this call for change, as it seeks to 'provide tools and concepts for allocating and managing land to achieve social, economic, and environmental objectives in areas where agriculture, mining, and other productive land uses compete with environmental and biodiversity goals' (Sayer et al. 2013: 8349).

SDG 2 targets span sectoral and geographic boundaries and involve multiple stakeholders along the entire supply chain, including consumers, producers, policymakers and many other actors. Operationalising integrated landscape management for forests and agriculture necessitates building partnerships among states, rural communities and industry. This requires new legislation, policies and novel forms of forest governance, such as co-management or community managed forests (HLPE Report 2017b). In particular, agricultural policy should be linked to health, education and trade policies that simultaneously promote human and planetary health (Willett 2019). This can help facilitate changes in behaviour and production.

Furthermore, a landscape approach calls for enhancing stakeholder capacity and coordination. It is pertinent that stakeholders are included in decision-making processes related to land management. Stakeholder involvement is increasingly recognised as a means to manage competing interests and as a way to be explicit about potential trade-offs. More than half of the national forest policies and programmes revised since 2007 in 42 countries now include measures to enhance the involvement of traditional forest users in decision-making processes (FAO 2014, HLPE Report 2017b).

\section{GENDER CONSIDERATIONS}

Social processes are key in decisions about forest-dependent livelihoods and forest-resource management, as well as governance processes and the 
distribution of benefits, with strongly differentiated gender roles and impacts (HLPE Report 2017b). These differences need to be considered while managing integrated landscapes. Women tend to grow a greater diversity of products, experiment more with folk varieties and landraces (and thus agrobiodiversity) and are often reliant on broader aspects of biodiversity for herbal medicine - linking both health and nutrition (Sunderland et al. 2011). Women are primarily responsible for food preparation and allocation and, as such, are usually the 'guardians' of household food security (WFP 2002). Yet women's access and control over land and resources is generally inferior to that of men in the same household or community (Agarwal 2018). Where women do have access to land, they tend to use it for food production, and income generated from such land is more likely to be utilised for the wellbeing of the household, whether for nutritional, health or other benefits (Wan et al. 2011).

Women and men tend to have differing tasks and responsibilities in the production and provision of food, including wild foods (Sunderland et al. 2014). Many women face gender-specific constraints that cut their productivity and limit their income-earning potential. There are gender gaps in access to land, credit, technology, employment and markets. Even though they are often primary resource users, women usually participate much less than men in formal land management and policy decisions (Leisher et al. 2016). Cultural, socio-economic and institutional factors contribute to gender inequality. These range from the societal perceptions of women's roles and the time women have to spend on domestic responsibilities and childcare to disparities in literacy, education, physical abilities, technical skills and access to training and extension services.

Target 2.3 specifically identifies women as a group of smallholder farmers that need support in order to achieve SDG 2. This is especially timely with the 'feminisation' of agriculture due to male out-migration and moves towards off-farm sources of income (Doss 2014, FAO 2017).

Many female farmers lack access to credit and extension services despite evidence suggesting that investment aimed at women leads to the increase of both farm and non-farm incomes at the household level. Although development policymakers and agencies increasingly recognise the crucial contributions of female farmers to food security, contemporary agricultural policies and research do not often directly address the needs of female farmers, focusing instead on traditionally male-dominated cropping practices. Such 'gender blindness' in the context of sustainable agricultural development is a risk to future food security given the major contributions of women to agriculture in the Global South. This underscores the importance of gender considerations 
in integrated landscape management planning processes. Moreover, a better understanding of what forest resources women are using for food and agriculture is useful for knowing what forest resources are of value to local communities and how to sustain them.

\subsection{Synergies and Trade-offs with Other SDGs}

Nutrition is an indispensable cog without which the SDG machine cannot function smoothly (Global Nutrition Report 2017). Poor nutrition has varied causes, many of which are intimately connected to work being undertaken to accomplish other SDGs. There is huge potential for making connections among the SDGs, but there is also the potential for incoherence. These trade-offs and synergies will have varied impacts on forests. The Global Nutrition Report (2017) finds that improving nutrition can have a powerful multiplier effect across the SDGs. Indeed, it indicates that it will be a challenge to achieve any of the SDGs without addressing nutrition. The report identifies five key fields where SDG 2 interacts at a broader scale with the other SDGs. In this section we use these five fields as a backdrop to discuss the trade-offs and synergies between SDG 2 and other SDGs, and how these impact forests.

1. Sustainable food production (relevant SDGs: 13, 14, 15) is key to nutrition outcomes. Agricultural yields will decrease as temperatures increase by more than $4^{\circ} \mathrm{C}$. Increased carbon dioxide will result in decreased protein, iron, zinc and other micronutrients in major crops consumed by much of the world (Ebi and Ziska 2018, Tigchelaar et al. 2018). Unsustainable fishing (SDG 14 Life below Water) threatens 17 per cent of the world's protein and a source of essential micronutrients (Golden et al. 2016). Policies and investments to maintain and increase the diversity of agricultural landscapes are needed to ensure small and medium-sized farms can continue to produce the 53-81 per cent of key micronutrients they do now (Herrero et al. 2017). As this chapter has explored, diversifying crops using sustainable agriculture practices and supporting small-scale farmers can enhance terrestrial biodiversity (SDG 15 Life on Land) and enable a food system that is more resilient in the face of climate change (SDG 13 Climate Action). While mechanisms for achieving SDG 15, such as protected areas, can benefit forest conservation, they can also restrict forest use and negatively impact the diets of forest-dependent communities. Sustainable food production approaches such as agroforestry and integrated landscape management show potential for harmonising the objectives of SDG 2 and SDG 15 (Timko et al. 2018). 
2. Strong systems of infrastructure (relevant SDGs: 6, 7, 8, 9, 11, 12) play key roles in providing safe, nutritious and healthy diets (SDG 2), clean water and sanitation (SDG 6) and more resilient communities overall (SDG 11). Contamination of food from unclean water and poor sanitation is associated with 50 per cent of under-nutrition; it leads to diarrhoea and can cause death, especially among young children. Improved infrastructure (SDG 9) can help deliver resources and services to underserved areas. Improved infrastructure such as cooling systems and storage facilities can reduce food waste. Furthermore, affordable and clean energy (SDG 7) can reduce the reliance on wood from forests for cooking fuel.

The impacts of improved infrastructure on forests and SDG 2 are twofold. First, infrastructure such as roads can help smallholder farmers access previously inaccessible markets and create decent work opportunities (SDG 8). This has the potential to encourage younger generations to continue participating in agriculture and incentivise farmers to continue farming diverse crops at a small scale, which would help reduce the formation of large-scale conglomerates that put pressure on forests. Second, improved access to remote areas may be beneficial for markets and delivering services, but building roads and other infrastructure can cause environmental harm, such as deforestation. In addition, improved access to these areas makes it easier for bigger industries to move in. This is where sustainable consumption (SDG 12) is important. Market-based mechanisms and certifications, like the examples discussed in Section 2.2.2, can help regulate the impacts of new infrastructure and industry on forests.

3. Health systems (relevant SDG: 3 ) have an important role in promoting infant and young child feeding, supplementation, therapeutic feeding, nutrition counselling to manage overweight and underweight concerns, and screening for diet-related noncommunicable diseases in patients. Yet our analysis shows that health systems are not delivering where they should: for example, only 5 per cent of children aged 0-59 months who need zinc treatment are receiving it. As discussed in Section 2.1, forests play a substantial role in the health and well-being of people (SDG 3). Forests provide nutritious food such as bushmeat, fruits and nuts, as well as providing wood for cooking meals. However, it should be noted that food can be a health risk, as in the case of bushmeat being linked to Ebola outbreaks. Overall, nutrition from forests improves health, helping keep people out of hospitals. The importance of eating nutritious food to maintain good health is accentuated in remote areas where access to healthcare is variable.

4. Equity and inclusion (relevant SDGs: 1, 4, 5, 8, 10, 16) matter for nutrition outcomes: ignoring equity in the distribution of wealth, education 
and gender will make it impossible to end malnutrition in all its forms. Approximately 767 million people live in extreme poverty, and 46 per cent of all stunting falls in this group (Global Nutrition Report 2017). This group is often neglected or excluded. Reflecting on the discussion in Section 2.2.2 about lack of support for smallholder farmers and women, the relationship between SDG 2 and SDG 4 (Quality Education) shows potential to reduce inequalities (SDG 10) among men and women (SDG 5 Gender Equality) and smallholder farmers and big industry. Workshops on conservation agriculture and other knowledge-sharing opportunities would be of great benefit to farmers and forest peoples. Education relates to decent work opportunities because skill building opens up new work opportunities and stimulates economic growth (SDG 8) and reduces poverty (SDG 1). The impacts on forests depend on the type of work and how growth is managed.

Another key intersection regarding equity and inclusion is the relationship between SDG 16 (Peace, Justice, and Strong Institutions), SDG 10 (Reduced Inequality) and SDG 2. SDG 16 aims to end corruption and exploitation and develop effective, accountable and transparent institutions at all levels. Transparency and regulation is very important for industries clearing or extracting forest resources. This is heightened by the fact that there are communities that do not have recognised rights over their land. In some cases, this has resulted in the loss of land to private companies. This can lead to deforestation by the company or by communities who have lost their farmland and moved to other forested areas. SDG 16 could improve tenuous land rights, securing land and resources vital to nutritious diets, as well as regulate industry to prevent the exploitation of forests.

5. Peace and stability (relevant SDG: 16) are vital to ending malnutrition. The proportion of under-nourished people living in countries in conflict and protracted crisis is almost three times higher than in other developing countries. Long-term instability can exacerbate food insecurity in many ways. In the worst-case scenario, conflict can lead to famine. When conflict or emergencies occur, nutrition must be included in disaster risk reduction and post-conflict rebuilding. On the other hand, forests act as a safety net during periods of crises and conflicts, as they provide food substitutes during times of insecurity. Additionally, peace and stability support law and order, which fosters an environment conducive to sustainable forest management. Whether managed at the national level or the community level, sustainable management conserves biodiversity, which is necessary for food security and nutrition. 


\subsection{Conclusion}

Under our current food system, forests are treated either as a space for agricultural expansion or a threatened resource needing protection from such expansion (HLPE Report 2017b). Breaking down this siloed thinking to realise that agriculture and forests are inextricably linked is an important step in achieving SDG 2. As this chapter highlights, our current food system is failing people and forests. Although we are producing more food than ever before, our population is characterised by both under- and over-malnutrition. Forests - exceptional sources of biodiversity and ecosystem services necessary for food and agriculture - are being destroyed for a limited selection of crops and livestock. A lack of diversity reduces nutrition and leaves our food system vulnerable to the vicissitudes of a changing climate.

SDG 2, specifically Targets 2.1-2.5, brings optimism to the future of forests and people. These targets emphasise biodiversity, sustainability and integration - all key ingredients of a resilient food system. Achieving SDG 2 should be based on the integration of food production and forests within the context of land management; this will both require and result in positive changes. For instance, major change will be required in both national and global governance systems and processes. The SDGs are an emerging opportunity in this regard, as they are all dependent on each other. Some SDGs have seamless synergies, such as SDG 2 and SDG 3, while others are bound to face trade-offs. We have reached a point where collaboration across sectors is needed more than ever. Forests can play an enormous role in facilitating this collaboration.

\section{References}

Aerts, R. and Honnay, O. 2011. Forest restoration, biodiversity and ecosystem functioning. BMC Ecology 11(1):29.

Agarwal, B. 2018. Gender equality, food security and the Sustainable Development Goals.

Current Opinion in Environmental Sustainability 34:26-32.

Aschemann-Witzel, J., de Hooge, I., Amani, P., Bech-Larsen, T. and Oostindjer, M. 2015.

Consumer-related food waste: Causes and potential for action. Sustainability 7(6):6457-77.

Bahadur, K., Dias, G. M., Veeramani, A. et al. 2018. When too much isn't enough: Does current food production meet global nutritional needs? PLoS ONE 13(10):e0205683.

Baudron, F., Chavarría, J. Y. D., Remans, R., Yang, K. and Sunderland, T. 2017. Indirect contributions of forests to dietary diversity in Southern Ethiopia. Ecology and Society 22(2):28.

Broegaard, R. B., Rasmussen, L.V ., Dawson, N. et al. 2017. Wild food collection and nutrition under commercial agriculture expansion in agriculture-forest landscapes. Forest Policy and Economics 84:92-101. 
Brussaard, L., Caron, P., Campbell, B. et al. 2010. Reconciling biodiversity conservation and food security: Scientific challenges for a new agriculture. Current Opinion in Environmental Sustainability 2(1-2):34-42.

Burlingame, B., Charrondiere, U. R., Dernini, S., Stadlmayr, B. and Mondovì, S. 2012. Food biodiversity and sustainable diets: Implications of applications for food production and processing. In Boye, J. I. and Arcand, Y. (eds) Green technologies in food production and processing. Boston: Springer, pp. 643-57.

Byron, N. and Arnold, M. 1997. What futures for the people of the tropical forests? Working Paper No. 19. Bogor, Indonesia: Center for International Forestry Research.

CEPI (Confederation of European Paper Industries) 2006. A comparison of the Forest Stewardship Council and the Programme for Endorsement of Forest Certification. Brussels: CEPI.

Chirwa, E. and Dorward, A. 2013. Agricultural input subsidies: The recent Malawi experience. Oxford: Oxford University Press.

Cockx, L., Colen, L. and De Weerdt, J. 2018. From corn to popcorn? Urbanization and dietary change: Evidence from rural-urban migrants in Tanzania. World Development 110:140-59.

Cramb, R. A., Colfer, C. J. P, Dressler, W. and Wadley, R. L. 2009. Swidden transformations and rural livelihoods in Southeast Asia. Human Ecology 37(3):323-46.

Cumming, G. S., Buerkert, A., Hoffmann, E. M. et al. 2014. Implications of agricultural transitions and urbanization for ecosystem services. Nature 515(7525):50-7.

Curtis, P. G., Slay, C. M., Harris, N. L., Tyukavina, A. and Hansen, M. C. 2018. Classifying drivers of global forest loss. Science 361(6407):1108-11.

Deutsch, C. A., Tewksbury, J. J., Tigchelaar, M. et al. 2018. Increase in crop losses to insect pests in a warming climate. Science 361(6405):916-19.

Doss, C. 2014. Collecting sex disaggregated data to improve development policies. Journal of African Economies 23(suppl_1):i62-i86.

Ebi, K. L. and Ziska, L. H. 2018. Increases in atmospheric carbon dioxide: Anticipated negative effects on food quality. PLoS Medicine 15(7):e1002600.

Ellis, E. C., Klein Goldewijk, K., Siebert, S., Lightman, D. and Ramankutty, N. 2010. Anthropogenic transformation of the biomes, 1700 to 2000. Global Ecology and Biogeography 19(5)589-606.

Fa, J. E., Olivero, J., Real, R. et al. 2015. Disentangling the relative effects of bushmeat availability on human nutrition in central Africa. Scientific Reports 5:8168.

FAO (Food and Agriculture Organization of the United Nations) 2011. Global food losses and food waste: Extent, causes and prevention. Rome: FAO.

FAO 2014. Strengthening the links between resilience and nutrition in food and agriculture. A discussion paper. Rome. Available at: www.fao.org/3/a-i3777e.pdf (Accessed 1 November 2018).

FAO 2015. The economic lives of smallholder farmers: An analysis based on household data from nine countries. Rome. Available at: www.fao.org/3/a-i5251e.pdf (Accessed 1 November 2018).

FAO 2016. State of the world's forests 2016. Forests and agriculture: Land-use challenges and opportunities. Rome: FAO.

FAO 2017. The future of food and agriculture: Trends and challenges. Rome: FAO. 
FAO 2019. The state of the world's biodiversity for food and agriculture. In Bélanger, J. and Pilling, D. (eds.) Commission on Genetic Resources for Food and Agriculture Assessments. Rome: FAO. Available at: www.fao.org/3/CA3129EN/CA3129EN.pdf (Accessed 26 February 2019).

FAO, IFAD, UNICEF, WFP and WHO 2017. The state of food security and nutrition in the world 2017. Building resilience for peace and food security. Rome: FAO.

Gibbs, H., Ruessch, A., Achard, F. et al. 2010. Tropical forests were the primary sources of new agricultural land in the 1980s and 1990s. Proceedings of the National Academy of Science 107:16732-7.

Global Nutrition Report 2017. Nourishing the SDGs. Bristol: Development Initiatives Poverty Research. Available at: http://globalnutritionreport.org/the-report/ (Accessed 1 November 2018).

Godfray, H. C. J., Beddington, J. R., Crute, I. R. et al. 2010. Food security: The challenge of feeding 9 billion people. Science 327(5967):812-18.

Golden, C., Allison, E. H., Cheung, W. W. et al. 2016. Fall in fish catch threatens human health. Nature 534(7607):317-20.

Gordon, I. J., Prins, H. H. and Squire, G. R. (eds.) 2017. Food production and nature conservation: Conflicts and solutions. London: Routledge.

Harari, Y. N. 2014. Sapiens: A brief history of humankind. New York: Random House.

Herrero, M., Thornton, P. K., Power, B. et al. 2017. Farming and the geography of nutrient production for human use: A transdisciplinary analysis. The Lancet Planetary Health 1(1):e33-42.

HLPE Report 2017a. Nutrition and food systems. A report by the High Level Panel of Experts on Food Security and Nutrition of the Committee on World Food Security. Rome.

HLPE Report 2017b. Sustainable forestry for food security and nutrition. A report by the High Level Panel of Experts on Food Security and Nutrition of the Committee on World Food Security. Rome.

IAEG-SDGs (Inter-Agency and Expert Group on SDG Indicators) 2016. United Nations Statistical Commission, 47th session. Report of the Inter-Agency and Expert Group on Sustainable Development Goal Indicators. Available at: https://sustainabledevelopment .un.org/sdg2 (Accessed 1 November 2019).

Ickowitz, A., Jones, A., Rowland, D., Powell, F. and Sunderland, T. 2019. Agricultural intensification, dietary diversity, and markets in the global food security narrative. Global Food Security 20:9-16.

Ickowitz, A., Rowland, D., Powell, B., Salim, M. A. and Sunderland, T. 2016. Forests, trees, and micronutrient-rich food consumption in Indonesia. PLoS ONE 11(5):e0154139.

Jamnadass, R. H., Dawson, I. K., Franzel, S. et al. 2011. Improving livelihoods and nutrition in sub-Saharan Africa through the promotion of indigenous and exotic fruit production in smallholders' agroforestry systems: A review. International Forest Review 13:338-54.

Jin, S. L., Schure, J., Ingram, V. and Byoung, I. I. 2017. Sustainable woodfuel for food security. A smart choice: Green, renewable and affordable. Working Paper. Rome: FAO. 
Khoury, C. K., Achicanoy, H. A., Bjorkman, A. D. et al. 2016. Origins of food crops connect countries worldwide. Proceedings of the Royal Society B 283(1832):20160792.

Khoury, C. K., Bjorkman, A. D., Dempewolf, H. et al. 2014. Increasing homogeneity in global food supplies and the implications for food security. Proceedings of the National Academy of Sciences 111(11):4001-6.

Kissinger, G., Herold, M. and de Sy, V. 2012. Drivers of deforestation and degradation: A synthesis report for REDD+ policymakers. Vancouver: Lexeme Consulting.

Kremen, C. and Merenlender, A. M. 2018. Landscapes that work for biodiversity and people. Science 362(6412):eaau6020.

Kuhnlein, H. V., Erasmus, B., Spigelski, D. and Burlingame, B. (eds.) 2009. Indigenous peoples' food systems: The many dimensions of culture, diversity and environment for nutrition and health. Rome: FAO.

Leisher, C., Temsah, G., Booker, F. et al. 2016. Does the gender composition of forest and fishery management groups affect resource governance and conservation outcomes? A systematic map. Environmental Evidence 5(1):6.

Lundgren, B. O. and Raintree, J. B. 1982. Sustained agroforestry. In Nestel, B. (ed.) Agricultural research for development: Potentials and challenges in Asia, The Hague: International Service for National Agricultural Research (ISNAR), pp. 37-49.

MacDicken, K. G., Sola, P., Hall, J. E. et al. 2015. Global progress towards sustainable forest management. Forest Ecology and Management 352:47-56.

Maezumi, S. Y., Alves, D., Robinson, M. et al. 2018. The legacy of 4,500 years of polyculture agroforestry in the eastern Amazon. Nature Plants 4 (8):40.

McMichael, P. 2005. Global development and the corporate food regime. In Buttel, F. H. and McMichael, P. (eds.) New directions in the sociology of global development, vol. 2. Bingley, West Yorkshire, UK: Emerald Group Publishing, pp. 265-99.

Mertz, O., Leisz, S., Heinimann, A. et al. 2009. Who counts? The demography of swidden cultivators. Human Ecology 37:281-9. doi:10.1007/s10745-009-9249-y.

Mills Busa, J. H. 2013. Deforestation beyond borders: Addressing the disparity between production and consumption of global resources. Conservation Letters 6(3):192-9.

Nair, P. K. N. 1993. An introduction to agroforestry. Dordrecht: Kluwer Academic Publishers.

Nasi, R., Taber, A. and van Vliet, N. 2011. Empty forests, empty stomachs? Bushmeat and livelihoods in the Congo and Amazon basins. International Forestry Review 13(3):355-68. Available at: www.cifor.org/publications/pdf_files/articles/ANasi1101.pdf (Accessed 1 November 2018).

Obiri, D. B., Bright, G. A., McDonald, M. A., Anglaaere, L. C. N. and Cobbina, J. 2007. Financial analysis of shaded cocoa in Ghana. Agroforestry Systems 71(2):139-49.

Obiri, D. B., Depinto, A. and Tetteh, F. 2011. Cost-benefit analysis of agricultural climate change mitigation options: The case of shaded cocoa in Ghana. Research Report. Washington, DC: International Food Policy Research Institute (IFPRI).

Padoch, C. and Sunderland, T. 2014. Managing landscapes for greater food security and improved livelihoods. Unasylva 64(241):3-13. 
Peng, L., Zhiming, F., Luguang, J., Chenhua, L. and Jinghua, Z. 2014. A review of swidden agriculture in Southeast Asia. Remote Sensing 6:1654-83. doi:10.3390/rs6021654.

Powell, B., Thilsted, S. H., Ickowitz, A., Termote, C., Sunderland, T. and Herforth, A. 2015. Improving diets with wild and cultivated biodiversity from across the landscape. Food Security 7(3):535-54.

REDD 2016. United Nations Programme on Reducing Emissions from Deforestation and Forest Degradation. UN REDD Programme Website. www.un-redd.org/ (Accessed 1 November 2018).

Reed, J., van Vianen, J., Foli, S. et al. 2017a. Trees for life: The ecosystems service contribution for trees to food production and livelihoods in the tropics. Forest Policy and Economics 84:62-71.

Reed, J., van Vianen, J., Barlow, J. and Sunderland, T. 2017b. Have integrated landscape approaches reconciled societal and environmental issues in the tropics? Land Use Policy 63:481-92.

Ricciardi, V., Ramankutty, N., Mehrabi, Z., Jarvis, L. and Chookolingo, B. 2018. How much of the world's food do smallholders produce? Global Food Security 17:64-72.

Ruf, F. and Schroth, G. 2004. Chocolate forests and monocultures: A historical review of cocoa growing and its conflicting role in tropical deforestation and forest conservation. In Schroth, G., Da Fonseca, G. A. B., Harvey, C. A. et al. (eds.) Agroforestry and biodiversity conservation in tropical landscapes. Washington, DC: Island Press.

Sayer, J., Sunderland, T., Ghazoul, J. et al. 2013. Ten principles for a landscape approach to reconciling agriculture, conservation, and other competing land uses. Proceedings of the National Academy of Sciences 110(21):8349-56.

Schipanski, M. E., MacDonald, G. K., Rosenzweig, S. et al. 2016. Realizing resilient food systems. Bioscience 66(7):600-10.

Shvidenko, A., Barber, C. V., Persson, R., Gonzalez, P. and Hassan, R. 2005. Forest and woodland systems. In Hassan. R., Scholes, R., and Ash, N. (eds.) Ecosystems and human well-being: Current state and trends. Vol. 1. Millennium Ecosystem Assessment series. Washington, DC: Island Press, pp. 585-622.

Smith, M. R. and Myers, S. S. 2018. Impact of anthropogenic $\mathrm{CO}_{2}$ emissions on global human nutrition. Nature Climate Change 8(9):834.

Springmann, M., Clark, M., Mason-D'Croz, D. et al. 2018. Options for keeping the food system within environmental limits. Nature 562:519-25.

Sunderland, T., Achdiawan, R., Angelsen, A. et al. 2014. Challenging perceptions about men, women, and forest product use: A global comparative study. World Development 64:S56-66.

Sunderland, T. C. H. 2011. Food security: Why is biodiversity important? International Forestry Review 13(3):265-74.

Swain, M., Blomqvist, L., McNamara, J. and Ripple, W. J. 2018. Reducing the environmental impact of global diets. Science of the Total Environment 610:1207-9.

Sylvester, O. and Segura, A. G. 2016. Landscape ethnoecology of forest food harvesting in the Talamanca Bribri Indigenous Territory, Costa Rica. Journal of Ethnobiology 36(1):215-33. 
Tigchelaar, M., Battisti, D. S., Naylor, R. L. and Ray, D. K. 2018. Future warming increases probability of globally synchronized maize production shocks. Proceedings of the National Academy of Sciences 115(26):6644-9.

Timko, J., Le Billon, P., Zerriffi, H. et al. 2018. A policy nexus approach to forests and the SDGs: Tradeoffs and synergies. Current Opinion in Environmental Sustainability 34:7-12.

Tomlinson, I. 2013. Doubling food production to feed the 9 billion: A critical perspective on a key discourse of food security in the UK. Journal of Rural Studies 29:81-90.

United Nations 2015. Resolution adopted by the General Assembly on 25 September 2015.Transformingour world: the 2030 Agenda for Sustainable Development. UN A/RES/70/1. Available at: www.un.org/ga/search/view_doc.asp?symbol=A/RES/70/1\&Lang=E (Accessed 20 July 2018).

Vandermeer, J., Aga, A., Allgeier, J. E. et al. 2018. Feeding Prometheus: An interdisciplinary approach for solving the global food crisis. Frontiers in Sustainable Food Systems 2:39.

Vinceti, B., Termote, C., Ickowitz , A. et al. 2013. The contribution of forests and trees to sustainable diets. Sustainability 5(11):4797-824. doi:10.3390/su5114797.

Vira, B., Wildburger, C. and Mansourian, S. (eds.) 2015. Forests, trees and landscapes for food security and nutrition. A Global Assessment Report. IUFRO World Series Vol. 33. Vienna: IUFRO.

Wan, M., Colfer, C. J. P. and Powell, B. 2011. Forests, women and health: Opportunities and challenges for conservation. International Forestry Review 13(3):369-87.

WFP (World Food Programme) 2002. Gender Policy 2003-2007: Enhanced commitments to women to ensure food security. Rome: WFP.

Willett, W., Rockström, J., Loken, B. et al. 2019. Food in the Anthropocene: The EAT-Lancet Commission on healthy diets from sustainable food systems. The Lancet 393(10170):447-92.

WRI (World Resources Institute) 2018. Creating a sustainable food future: A menu of solutions to feed nearly 10 billion people by 2050. Synthesis Report. Washington, DC: WRI.

Wunder, S., Börner, J., Shively, G. and Wyman, M. 2014. Safety nets, gap filling and forests: A global-comparative perspective. World Development 64:S29-42. 